\title{
Author Correction: The genome of Prasinoderma coloniale unveils the existence of a third phylum within green plants
}

Linzhou Li, Sibo Wang, Hongli Wang, Sunil Kumar Sahu (D), Birger Marin (D, Haoyuan Li, Yan Xu, Hongping Liang, Zhen Li ID, Shifeng Cheng, Tanja Reder, Zehra Çebi, Sebastian Wittek, Morten Petersen, Barbara Melkonian, Hongli Du, Huanming Yang, Jian Wang, Gane Ka-Shu Wong (D), Xun Xu (D), Xin Liu D, Yves Van de Peer (D), Michael Melkonian and Huan Liu (iD

Correction to: Nature Ecology \& Evolution https://doi.org/10.1038/s41559-020-1221-7, published online 22 June 2020.

In the Supplementary Information for this Article originally published, in the 'Diagnoses_Prasinodermophyta' file of Supplementary Data 1, Pyramimonadophyceae was described as a new class. However, this class was previously described in an article by Daugbjerg et al. ${ }^{1}$ and thus the description was removed.

Additionally, this file was originally presented in Word format, but according to Articles 29.1 and 29.3 of the 'International Code of Nomenclature for algae, fungi, and plants's, the nomenclatural acts were thus not effectively published because they were not presented in a portable document format (PDF). To effectively publish the nomenclatural novelties, the file has now been provided as a PDF file titled 'Diagnoses_Prasinodermophyta_corrected'.

These errors have now been corrected.

\section{References}

1. Daugbjerg, N., Fassel, N. M. D. \& Moestrup, Ø. Microscopy and phylogeny of Pyramimonas tatianae sp. nov. (Pyramimonadales, Chlorophyta), a scaly quadriflagellate from Golden Horn Bay (eastern Russia) and formal description of Pyramimonadophyceae classis nova. Eur. J. Phycol. 55, 49-63 (2020).

2. Turland, N. J. et al. (eds) International Code of Nomenclature for algae, fungi, and plants (Shenzhen Code) adopted by the Nineteenth International Botanical Congress Shenzhen, China, July 2017 Regnum Vegetabile 159 (Koeltz Botanical Books, 2018); https://doi.org/10.12705/Code.2018

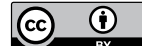

Open Access This article is licensed under a Creative Commons Attribution 4.0 International License, which permits use, sharing, adaptation, distribution and reproduction in any medium or format, as long as you give appropriate credit to the original author(s) and the source, provide a link to the Creative Commons license, and indicate if changes were made. The images or other third party material in this article are included in the article's Creative Commons license, unless indicated otherwise in a credit line to the material. If material is not included in the article's Creative Commons license and your intended use is not permitted by statutory regulation or exceeds the permitted use, you will need to obtain permission directly from the copyright holder. To view a copy of this license, visit http://creativecommons.org/licenses/by/4.0/.
}

Published online: 16 July 2020

https://doi.org/10.1038/s41559-020-1268-5

(c) The Author(s), under exclusive licence to Springer Nature Limited 2020 